University of Nebraska - Lincoln DigitalCommons@University of Nebraska - Lincoln

2009

\title{
Crop Effects on Closed System Element Cycling for Human Life Support in Space
}

C. L. Mackowiak

University of Florida, echo13@ufl.edu

P. R. Grossl

Utah State University

R. M. Wheeler

NASA Biological Sciences, Kennedy Space Center, Florida, USA

Follow this and additional works at: http://digitalcommons.unl.edu/nasapub

Mackowiak, C. L.; Grossl, P. R.; and Wheeler, R. M., "Crop Effects on Closed System Element Cycling for Human Life Support in Space" (2009). NASA Publications. 180.

http://digitalcommons.unl.edu/nasapub/180

This Article is brought to you for free and open access by the National Aeronautics and Space Administration at DigitalCommons@University of Nebraska - Lincoln. It has been accepted for inclusion in NASA Publications by an authorized administrator of DigitalCommons@University of Nebraska - Lincoln. 


\title{
Crop Effects on Closed System Element Cycling for Human Life Support in Space
}

\author{
C. L. Mackowiak, ${ }^{1}$ P. R. Grossl, ${ }^{2}$ and R. M. Wheeler ${ }^{3}$ \\ ${ }^{1}$ Institute of Food and Agricultural Science-North Florida Research and Education \\ Center, University of Florida, Quincy, Florida, USA \\ ${ }^{2}$ Plants, Soils, and Climate, Utah State University, Logan, Utah, USA \\ ${ }^{3}$ NASA Biological Sciences, Kennedy Space Center, Florida, USA
}

\begin{abstract}
Nutrient recycling in a space-based Bioregenerative Life Support System (BLSS) will require an understanding of nutrient dosage effects on crop production, plant tissue partitioning, and geochemical fates within crop systems. Sodium $\left(\mathrm{Na}^{+}\right)$, fluoride $\left(\mathrm{F}^{-}\right)$, and iodide $\left(\mathrm{I}^{-}\right)$are found in human waste streams. These elements were examined using crops in hydroponic systems. Lettuce, radish, spinach, and beet were used to study $\mathrm{Na}^{+}$ uptake and tolerance. Spinach, lettuce, and radish growth were inhibited at $8.0 \times 10^{-2}$ $\mathrm{M} \mathrm{Na}^{+}$compared to the control. Beet growth improved at 2.0 and $4.0 \times 10^{-2} \mathrm{M} \mathrm{Na}^{+}$ compared to the control. Rice plants were used to study $\mathrm{F}^{-}$and $\mathrm{I}^{-}$uptake and tolerance. Rice growth was inhibited at $5.0 \times 10^{-4} \mathrm{M} \mathrm{F}^{-}$and at $5.0 \times 10^{-6} \mathrm{M} \mathrm{I}^{-}$. Solution redox and sorption reactions were predicted with the aid of a chemical equilibrium model. A simulation model was used to predict element fates.
\end{abstract}

Keywords: beet, fluoride, geochemical model, iodide, lettuce, life support, radish, rice, sodium, spinach

\section{INTRODUCTION}

Plants will play a key role in the life support functions of human habitats for extended space missions to planetary surfaces (Drysdale, 1995). This includes nutrient cycling between plants and humans (Barta et al., 1999; Wheeler and Strayer, 1997; Wheeler et al., 2001). Inorganic elements lost through plant

Received 18 January 2007; accepted 17 May 2007.

Address correspondence to C. L. Mackowiak, IFAS-NFREC, 155 Research Rd., Quincy, FL, 32351, USA. E-mail: echo13@ufl.edu 
and human waste streams will be captured and recycled back into the human diet. There are several elements essential to humans but not to plants. The list of human essential elements is periodically reviewed and updated (Neilsen, 1998; Neilsen, 2000; Spears, 1999; Ulthus and Seaborn, 1996). Many of these elements or nutrients are not routinely tested for plant responses in cropping systems, unless a plant-derived element is an important contributor (e.g., calcium, iron) to the human diet.

Of all elements essential to humans but not plants, sodium $(\mathrm{Na})$ is required in the largest quantity and thus, it will likely have the greatest short-term impact on human waste recycling in the plant system. Sodium is quite soluble (existing as $\mathrm{Na}^{+}$in aqueous solutions) and will likely remain bioavailable once it enters the crop production system. The United States recommended daily allowance (RDA) is $3 \mathrm{~g}$ and the NASA recommendation for space is from 1.5 to $3.5 \mathrm{~g}$ (Lane et al., 1996). In general, $\mathrm{Na}$ is nonessential to higher plants, but it is essential to some $\mathrm{C}_{4}$ species, e.g., amaranth, saltbush (Brownwell, 1979) and is beneficial to several plant species, including a few on the NASA Bioregenertive Life Support System (BLSS) candidate crop list (Wheeler and Strayer, 1997). The BLSS crops benefiting from $\mathrm{Na}$ belong to the Chenopodiaceae family, e.g., spinach, chard, and beet. These crops not only tolerate $\mathrm{Na}$ but they can substitute $\mathrm{Na}$ for potassium (K), which results in higher $\mathrm{Na}$ accumulation in edible biomass (Subbarao et al., 1999).

The RDA for fluorine $(\mathrm{F})$ has not been established but NASA recommends $4 \mathrm{mg} \mathrm{d}^{-1} \mathrm{~F}$ as $\mathrm{F}^{-}$(Lane et al., 1996). There has not been definitive proof that $\mathrm{F}$ is an essential element but studies have shown that $\mathrm{F}$ nutrition mitigates dental caries (tooth decay) and may improve bone mass (National Academy of Sciences, 1989). Unlike Na, F might become less bioavailable in crop production systems over time. Fluorine, which typically exists as the fluoride ion $\left(\mathrm{F}^{-}\right)$in solution, readily reacts with calcium $(\mathrm{Ca})$ and magnesium $(\mathrm{Mg})$ to form solid-phases. In addition, $\mathrm{F}^{-}$is incorporated into phosphorus $(\mathrm{P})$ solid-phases to form fluoroapatite. Plants do not appear to profit from F nutrition and several reports have shown $\mathrm{F}^{-}$supplied to plants above $1 \mathrm{mM}$ may be toxic (Bar-Yosef and Rosenberg, 1988; Hara et al., 1977; Mackowiak et al., 2003; Stevens et al., 1997).

Iodine (I) is a proven essential nutrient where RDA and NASA concur with a daily requirement of $0.15 \mathrm{mg} \mathrm{d}^{-1}$. This element exists in multiple valence states and thus is affected by the reduction/oxidation (redox) of its environment. In a highly oxidized environment, I exists as iodate $\left(\mathrm{IO}_{3}{ }^{-}\right)$and under more reduced conditions iodide $\left(\mathrm{I}^{-}\right)$dominates. However, if $\mathrm{I}^{-}$becomes oxidized, it may convert to volatile elemental iodine $\left(\mathrm{I}_{2}\right)$ and escape into the atmosphere. In addition, I has been shown to combine with carbon in waste streams to form an array of potentially harmful halogenated organic compounds (Silverstein et al., 1994). Due to the ability of $I_{2}$ to function as a bactericide, NASA has used it in their water treatment system for space. In this instance $I_{2}$ is the active form (bactericide) that quickly reduces to $\mathrm{I}^{-}$after contact, resulting in some 
$\mathrm{I}^{-}$remaining in the water after treatment (Colombo et al., 1978). This potentially provides an additional source of I for plants, and humans (Gillman et al., 2001). Plant toxicity has been observed with $\mathrm{I}^{-}$concentrations as low as $10 \mu \mathrm{M}$ but plants can tolerate nearly 10 -fold higher $\mathrm{IO}_{3}{ }^{-}$concentrations (Mackowiak and Grossl, 1999).

The objectives of this research were 1) Compile plant yield and nutrient uptake data from NASA candidate crop dose-response studies with $\mathrm{Na}^{+}, \mathrm{F}^{-}$, and $\left.\mathrm{I}^{-}, 2\right)$ determine target element fates in a hypothetical BLSS hydroponic-based crop system using the dose-response data, geochemical equilibrium modeling and simulation modeling of target element mass transfers within a BLSS, and 3) discuss target element recycling scenarios and contaminant contingencies.

\section{MATERIALS AND METHODS}

\section{Plant Culture}

Representative crop species were 1) Lactuca sativus L. 'Waldmann's Green', Raphanus sativas L. 'Cherry Belle', Beta vulgaris L. 'Klein Bol', and Spinacia oleracea L. 'Nordic IV' for Na studies; 2) Oryza sativa L. '29-Lu-1' for I studies; and 3) 'USU-Super Dwarf' for F studies. Studies with Na were conducted in reach-in controlled environment chambers, whereas I and F studies were conducted in a greenhouse. The environmental parameters for all studies were within the envelope recommended for BLSS crop systems (Barta et al., 1999; Wheeler et al., 2001) and the environmental conditions for each nutrient study are summarized (Table 1). In the Na studies, water additions and nutrient solution $\mathrm{pH}$ were automatically controlled, whereas manual control (daily basis) was used for the other studies. The nutrient solution composition and maintenance methods used for the Na studies are the same used in a previous study with tomato and soybean (Mackowiak et al., 1999). Details of nutrient solution

Table 1

Environmental conditions for plant studies

\begin{tabular}{llccccc}
\hline Element & Crop & $\begin{array}{c}\text { Duration } \\
(\text { days })\end{array}$ & $\begin{array}{c}\text { Irradiance } \\
\left(\mathrm{mol} \mathrm{m}^{-2} \mathrm{~d}^{-1}\right)\end{array}$ & $\begin{array}{c}\text { Temperature } \\
\left({ }^{\circ} \mathrm{C}\right)\end{array}$ & $\begin{array}{c}\mathrm{RH}^{*} \\
(\%)\end{array}$ & $\begin{array}{c}\mathrm{CO}_{2} \\
\left(\mu \mathrm{mol} \mathrm{mol}^{-1}\right)\end{array}$ \\
\hline $\mathrm{Na}$ & beet & 35 & 13 & $23 \pm 0.3$ & $74 \pm 9$ & $1180 \pm 166$ \\
& lettuce & 21 & 13 & $23 \pm 0.8$ & $76 \pm 10$ & $1185 \pm 137$ \\
& radish & 21 & 13 & $23 \pm 0.3$ & $74 \pm 9$ & $1168 \pm 158$ \\
& spinach & 21 & 13 & $23 \pm 0.4$ & $73 \pm 9$ & $1195 \pm 62$ \\
$\mathrm{~F}$ & rice & 63 & 29 & $28 / 22 \pm 5$ & ambient & ambient \\
$\mathrm{I}$ & rice & 113 & 16 & $29 / 22 \pm 5$ & ambient & ambient \\
\hline
\end{tabular}

${ }^{*} \mathrm{RH}=$ relative humidity. 
Table 2

Plant culture conditions

\begin{tabular}{|c|c|c|c|c|}
\hline Element & Crop & Salt & Hydroponic system* & $\mathrm{pH}^{\dagger}$ \\
\hline \multirow[t]{4}{*}{$\mathrm{Na}$} & beet & $\mathrm{NaCl}$ & Recirculating nutrient film technique & $5.8 \pm 0.3$ \\
\hline & spinach & & $"$ & $5.6 \pm 0.9$ \\
\hline & radish & & $"$ & $5.7 \pm 0.2$ \\
\hline & lettuce & & $"$ & $5.7 \pm 0.5$ \\
\hline $\mathrm{F}$ & rice & $\mathrm{KF}$ & Aerated solution culture & $5.0 \pm 0.5$ \\
\hline I & rice & $\mathrm{KI}$ and $\mathrm{KIO}_{3}$ & Aerated solution culture & $5.4 \pm 0.4$ \\
\hline
\end{tabular}

*The hydroponic systems varied as to their construction and nutrient solution recipes. Details for the Na, F, and I studies are given in Mackowiak et al. (1999), Mackowiak et al. (2003) and Mackowiak and Grossl (1999), respectively.

${ }^{\dagger}$ The solution $\mathrm{pH}$ was automatically monitored and controlled in the $\mathrm{Na}$ studies and it was manually checked and adjusted each day in the F and I studies. All studies used either $\mathrm{HNO}_{3}$ or $\mathrm{KOH}$, as needed for $\mathrm{pH}$ control.

composition and maintenance for the F and I studies are described in detail elsewhere (Mackowiak et al., 2003; Mackowiak and Grossl, 1999). The hydroponic system descriptions and $\mathrm{pH}$ set points are given (Table 2). The iodine study included $\mathrm{I}^{-}$as part of the refill nutrient solution, where the concentration in the refill solution contained $20 \%$ of the initial $\mathrm{I}^{-}$treatment concentration, in addition to the plant essential elements. In contrast, the other studies only used initial doses of the target elements rather than continual additions via the hydroponic nutrient refill solutions.

\section{Harvest and Analyses}

All plant biomass was oven-dried $\left(65^{\circ} \mathrm{C}\right)$, weighed and ground ( $2 \mathrm{~mm}$ mesh) prior to tissue analysis. Roots were patted with paper towel to remove excess water and then dried. Roots were not rinsed in order to maintain any solid phases that might have developed during some of the studies. Sodium was determined by inductively coupled plasma spectrometry (ICP). Iodine (as $\mathrm{I}^{-}$) was determined by an alkaline dry-ashing procedure (Joepke et al., 1996; Mackowiak and Grossl, 1999) and digests analyzed colorimetrically, using a Lachat autoanalyzer (Lachat Instruments, Milwaukee, WI). Fluorine (as $\mathrm{F}^{-}$) was determined by an alkaline fusion ashing and selective ion electrode procedure (McQuaker and Gurney, 1977). Nutrient solution Na was determined by ICP. Nutrient solution I was determined colorimetrically, using the Lachat autoanalyzer, and nutrient solution $\mathrm{F}$ (as $\mathrm{F}^{-}$) determined with an ion selective electrode. Oven-dried root subsamples were taken from the F study, mounted on stubs, coated with carbon using an ion beam sputterer and examined with a 
Hitachi S-4000 scanning electron microscope (SEM). Energy dispersive x-ray (EDX) digital dot mapping for $\mathrm{Ca}$ and $\mathrm{F}$ was performed with the Link EXL 1000 ECX system (Oxford Instruments, Oak Ridge, TN).

A completely randomized experimental design was used in the $\mathrm{Na}$ trials. Due to chamber size constraints, the study was run three times in order to obtain three treatment replications. Analysis of variance (ANOVA) proc GLM (SAS, Cary, NC) was used to analyze yield data and means comparisons performed using least significant differences (LSD). Tissue was combined among trials so only single values are available for tissue elemental content. The F and I trials were conducted as randomized block designs with three replicates (tubs) per treatment. The F treatments were analyzed by ANOVA (Prism, Graphpad Software, San Diego, CA) and means comparisons were performed using LSD. The I treatments were analyzed by ANOVA (Minitab 9.1, Minitab Inc., State College, PA) and planned comparisons were used to compare treatments with the control and among treatments.

\section{Geochemical Modeling}

A chemical equilibrium model was used to individually model $\mathrm{Na}, \mathrm{F}$, and I in hydroponic nutrient solutions. Although there are several equilibrium models available, GEOCHEM-PC (Parker et al., 1995) was chosen because it adequately models hydroponic nutrient solutions. Assumptions and conditions for the model were, 1) the nutrient solution composition remained constant during the plant study, 2) solution $\mathrm{pH}$ remained constant, 3) redox conditions were not considered, and 4) mixed solids were not allowed to form. In addition, the model's $\mathrm{CaF}_{2}$ equilibrium constant $\left(\mathrm{K}^{\circ}\right)$ was greater than several reported values, so it was replaced with a value from Elrashidi and Lindsey (1986).

\section{Simulation Modeling}

A simulation software program (Stella 6.0, High Performance Systems, Hanover, NH) was used to individually model $\mathrm{Na}, \mathrm{F}$, and I stocks (amount residing in system components) and fluxes in a hypothetical BLSS. Model parameters included a single person crew, $100 \%$ vegetarian diet using a hydroponic cropping system containing multiple-aged plants (steady-state) with a daily total biomass harvest of $1250 \mathrm{~g}$ dry mass, and external element resupply, as required. This equated to $50 \mathrm{~m}^{2}$ crop growing area and a supporting nutrient solution volume of $500 \mathrm{~L}$ per person. The estimated crop production area requirements were somewhat large considering the high productivities that have been achieved with individual crop species (Bugbee and Salisbury, 1988; Edeen et al., 1993; Stutte et al., 1999) but it is a practical estimate assuming a mix of species and productivities (Wheeler et al., 1996). This simulation model 
was based on a human $(70 \mathrm{~kg})$ ingesting recommended daily quantities of target elements, i.e., $3000 \mathrm{mg}$ (130.4 mmoles) Na, $4 \mathrm{mg} \mathrm{F}$ (211 $\mu$ moles), and 0.15 mg (118 $\mu$ moles) I and excreting these amounts each day via waste products. The model was also based on the waste processing system returning $100 \%$ of the target elements to the crop system.

\section{RESULTS AND DISCUSSION}

\section{Plant Dose-Response and Element Composition}

Sodium response was dependent upon crop species. Compared to the control (no Na), beet biomass increased with 20 and $40 \mathrm{mM} \mathrm{Na}$, spinach was unaffected, and lettuce and radish biomass declined at $80 \mathrm{mM} \mathrm{Na}$ (Figure 1a). These results coincide with salinity tolerance values for herbaceous crops (Richards, 1954).

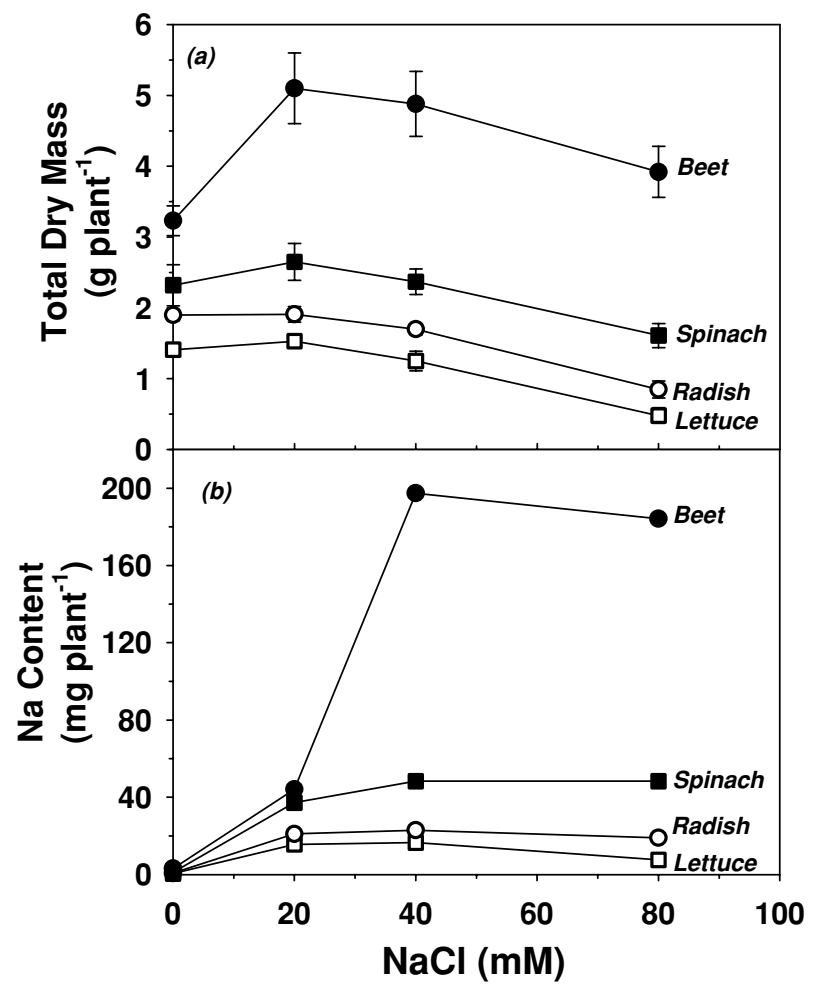

Figure 1. Sodium effect on total biomass yield (a) and Na content in the total plant (b) at 21 days for lettuce, radish, and spinach, and 28 days for beet. Vertical bars = standard errors (a). 


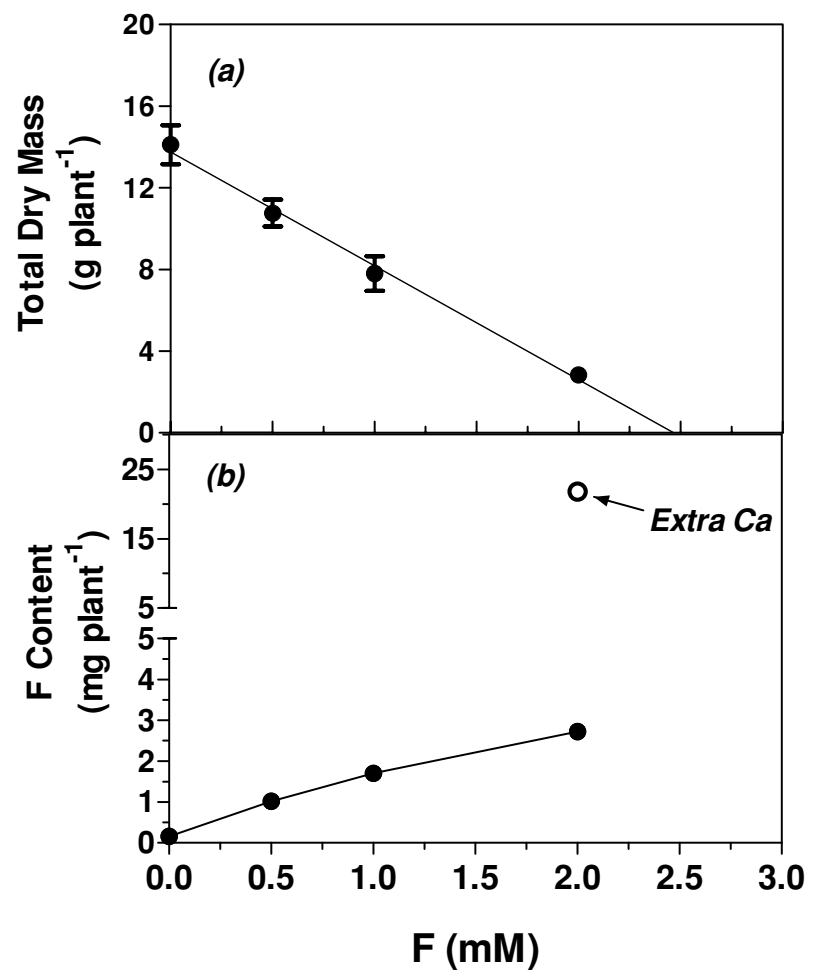

Figure 2. Fluoride effect on total biomass yield (a) and F content in the total plant (b) at 63 days for rice 'Super dwarf'. Vertical bars = standard error (a).

Sodium removal by beet was greatest and least for radish and lettuce (Figure 1b). Based on the growth response and $\mathrm{Na}$ accumulation data, it appeared that approximately $40 \mathrm{mM}$ was the upper solution concentration limit for crops in this system.

Rice growth was affected by all levels of $\mathrm{F}$, where biomass decreased linearly with increasing solution $\mathrm{F}^{-}$(Figure 2a). This study did not continue through seed maturity but results from a previous study showed that rice seed F was less than $0.5 \%$ of shoot tissue concentrations (Mackowiak et al., 2003). Plants from this study had begun seed fill at the time it was terminated (63 days). Harvested panicles (immature seed + chaff) contained less than $19 \mathrm{mg} \mathrm{kg}^{-1}$ $\mathrm{F}$ (5\% of leaf values) for the $2 \mathrm{mM} \mathrm{F}$ treatment and most of the F was likely associated with chaff tissue. This suggests that $\mathrm{F}$ is not readily transported from xylem to phloem and so little would be expected in the grain. The total F content increased per plant as solution F increased (Figure 2b). It is interesting to note that when additional $\mathrm{Ca}$ was added to the nutrient solution (from $1 \mathrm{mM}$ to $2 \mathrm{mM}$ $\mathrm{Ca}$ ), total plant $\mathrm{F}$ increased from 2.7 to $22 \mathrm{mg} \mathrm{plant}^{-1}$ (Figure 2b). Over $90 \%$ of 


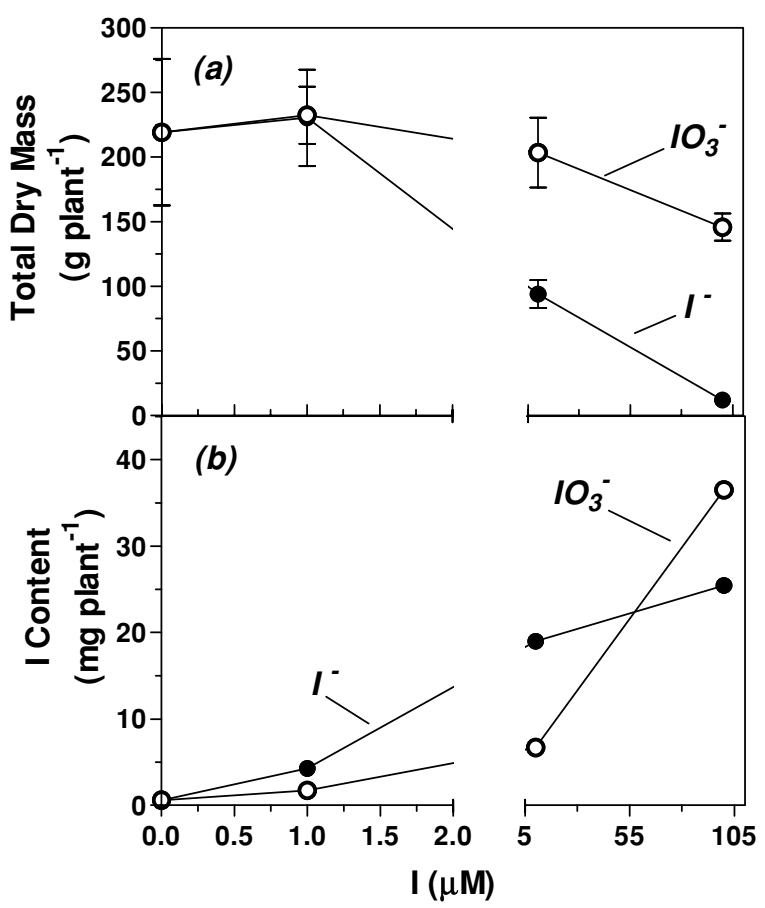

Figure 3. Iodine effect on total biomass yield (a) and I content in the total plant (b) at 113 days for rice '29-Lu-1'. Vertical bars = standard error (a).

the plant $\mathrm{F}$ in the $2 \mathrm{x}$ Ca treatment was associated with the root, mostly coating the surface as a $\mathrm{CaF}_{2}$ solid phase, as determined by EDX spectroscopy. The solid phases are addressed further in the geochemical interactions discussion.

Iodine valency affected I toxicity in rice. The more reduced form, $\mathrm{I}^{-}$, was more inhibitory than the oxidized form, $\mathrm{IO}_{3}{ }^{-}$(Figure 3a). Although there tended to be less growth with increasing solution $\mathrm{IO}_{3}{ }^{-}$, the differences were not significant. As with the other test elements, increasing solution I concentrations resulted in a greater accumulation of I in the plant (Figure 3b). At $100 \mu \mathrm{M} \mathrm{I}$, there was actually more total $\mathrm{I}$ removed from solution by the $\mathrm{IO}_{3}{ }^{-}$treatment than with the $\mathrm{I}^{-}$treatment since plant growth was greatly inhibited with the $\mathrm{I}^{-}$ treatment. Although it was not addressed in this trial, $\mathrm{I}_{2}$, which has been used to treat International Space Station water (Parker et al., 1999) is even more inhibitory to plants than $\mathrm{I}^{-}$. In a recent study, I supplied to rice at $20 \mu \mathrm{M}$ with an $\mathrm{I}_{2}: \mathrm{I}^{-}$ratio of $0.6: 1.0$ resulted in a $70 \%$ reduction in growth compared to a $35 \%$ reduction in growth when I was provided solely as $\mathrm{I}^{-}$(Mackowiak et al., 2005). The $I_{2}$ form is unstable in non-acidic solutions where it can be readily (within hours) reduced to $\mathrm{I}^{-}$and volatilized to some extent. 


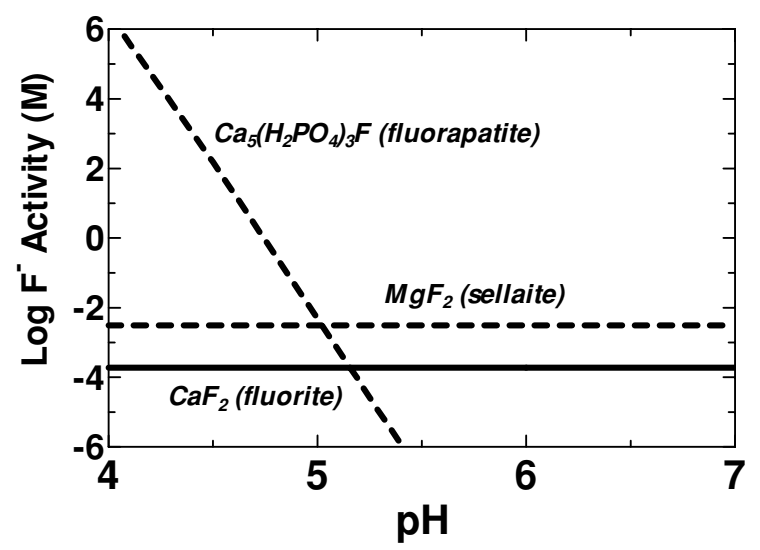

Figure 4. Fluorine stability diagram where $\mathrm{F}^{-}$activity is a function of solution $\mathrm{pH}$. Fluorite controls $\mathrm{F}^{-}$activity below $\mathrm{pH} 5.2$ and fluoroapatite controls $\mathrm{F}^{-}$activity from pH 5.2 to 7.0. Adapted from Erashidi and Lindsey (1986).

\section{Geochemical Interactions}

Sodium remains soluble at high $\mathrm{NaCl}$ concentrations (up to $6 \mathrm{M}$ ). Sodium readily forms complexes with $\mathrm{Cl}, \mathrm{CO}_{2(\mathrm{~g})}$, and $\mathrm{SO}_{4}{ }^{2-}$, which have little effect on overall $\mathrm{Na}$ bioavailability. Sodium may form solids with other elements, particularly $\mathrm{CO}_{3}{ }^{2-}, \mathrm{Al}$, and $\mathrm{Si}$ but it is unlikely to occur in these hydroponic cropping systems.

Fluoride readily reacts with several cationic species, such as $\mathrm{Ca}^{2+}, \mathrm{Mg}^{2+}$, $\mathrm{Fe}^{3+}$, and $\mathrm{Na}^{+}$, as well as $\mathrm{PO}_{4}{ }^{3-}$, to form mixed solid phases. The fluoride interactions of greatest concern in a BLSS are with $\mathrm{Ca}$ and $\mathrm{Mg}$ (Figure 4). The model predicts that under acidic conditions ( $\mathrm{pH}$ less than approximately 5.2), $\mathrm{CaF}_{2}$ controls $\mathrm{F}^{-}$activity in solution, to approximately $0.15 \mathrm{mM}(2.9 \mathrm{ppm})$. If more $\mathrm{F}^{-}$is added to solution, it would likely form a $\mathrm{CaF}_{2}$ precipitate, thereby retaining solution equilibrium near $0.15 \mathrm{mM}$ in the hydroponic solution. At higher $\mathrm{pH}$ values, fluoroapatite $\left.\left[\mathrm{Ca}_{5}\left(\mathrm{PO}_{4}\right)_{3} \mathrm{~F}\right)\right]$ controls $\mathrm{F}$ activity and therefore soluble $\mathrm{F}^{-}$concentrations would likely decline at a correspondingly higher solution $\mathrm{pH}$ (Figure 4). Based on the geochemical model used in this study and a nutrient solution $\mathrm{pH}$ of approximately 5.0 , initial solution $\mathrm{F}^{-}$at $2 \mathrm{mM}$ was predicted to decrease to $0.53 \mathrm{mM}$ at equilibrium because of the formation of $\mathrm{Ca}-\mathrm{F}$ solid phases. Additional $\mathrm{Ca}$ (from $1 \mathrm{mM}$ to $2 \mathrm{mM}$ ) would reduce solution $\mathrm{F}^{-}$further to $0.26 \mathrm{mM}$. Doubling nutrient solution Ca greatly increased the amount of $\mathrm{F}$ associated with root tissue (Figure 2b). Root ICP analysis showed total root $\mathrm{Ca}$ had increased from $0.63 \%$ to $5.12 \%$ in the $1 \mathrm{x} \mathrm{Ca}$ and $2 \mathrm{x} \mathrm{Ca}$ treatments, respectively. Root surface EDX spectroscopy identified $\mathrm{F}$ and $\mathrm{Ca}$ as the major elements found on the root, suggesting that a Ca-F solid phase 


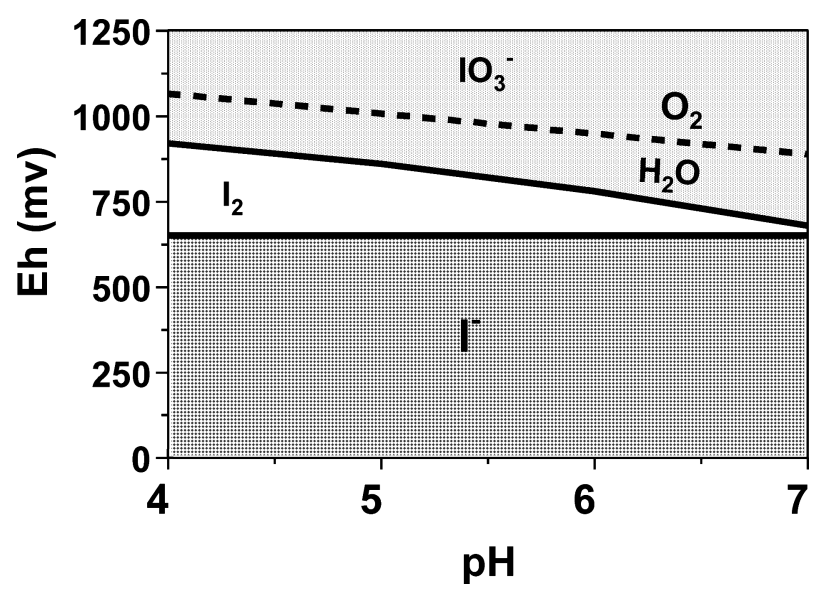

Figure 5. Fields of stability for I species as a function of $\mathrm{pH}$ in a natural aquatic system. The dashed line represents the redox equilibrium of $\mathrm{H}_{2} \mathrm{O}$ with $\mathrm{O}_{2}$, where decreasing the electron activity (an increased Eh) would result in $\mathrm{O}_{2}$ evolution. The Eh of a wellaerated hydroponic solution ranges approximately 400 to 700 mv. Adapted from Fuge and Johnson (1986).

coated the root surface rather than these elements being sequestered within the root.

Iodine will not form precipitates in a BLSS system unless heavy metal contaminants, i.e., $\mathrm{Ag}$, or $\mathrm{Hg}$, are present (Lindsay, 1979), resulting in solids and gasses, respectively. Iodine exists in multiple oxidation states, which greatly determine the degree of toxicity to plants and microbes. The most common oxidized I species is $\mathrm{IO}_{3}{ }^{-}$and the most common reduced form is $\mathrm{I}^{-}$(Figure 5). Typical equilibrium redox values are around 400 to $700 \mathrm{mv}$ (pe $=6.8$ to 11.8) for a well-aerated hydroponic system. At equilibrium, $\mathrm{IO}_{3}{ }^{-}$should not exist at oxidation states below $700 \mathrm{mv}$ (Figure 5). However, we found that the majority of added $\mathrm{IO}_{3}{ }^{-}$remained as $\mathrm{IO}_{3}{ }^{-}$for at least 100 days in previous plant studies (Mackowiak and Grossl, 1999), suggesting that the kinetics of $\mathrm{IO}_{3}{ }^{-}$to lower oxidation states are slow. The $\mathrm{I}^{-}$species is likely more bioavailable to plants than $\mathrm{IO}_{3}{ }^{-}$(Böszörményi and Cseh, 1960; Mackowiak et al., 2005; Umaly and Poel, 1971). If reduction of $\mathrm{IO}_{3}{ }^{-}$to $\mathrm{I}^{-}$was quick, plant growth inhibition would likely have been greater with the corresponding $\mathrm{IO}_{3}{ }^{-}$treatments (Figure 3a). The relative toxicity of I to plants is $\mathrm{I}_{2}>\mathrm{I}^{-}>\mathrm{IO}_{3}{ }^{-}$. In a BLSS, $\mathrm{I}^{-}$may become available as a by-product of water treatment, such as the microbial check valve (Colombo et al., 1978) and $\mathrm{I}^{-}$is the main form found in human urine (Michalke and Scramel, 1999). If I resins are used to treat potable water, a post treatment will be needed to minimize residual water $\mathrm{I}^{-}$and possible I volatilization. Some techniques, such as carbon water filters, are under consideration for treating residual $\mathrm{I}^{-}$in water (Parker et al, 1999). 


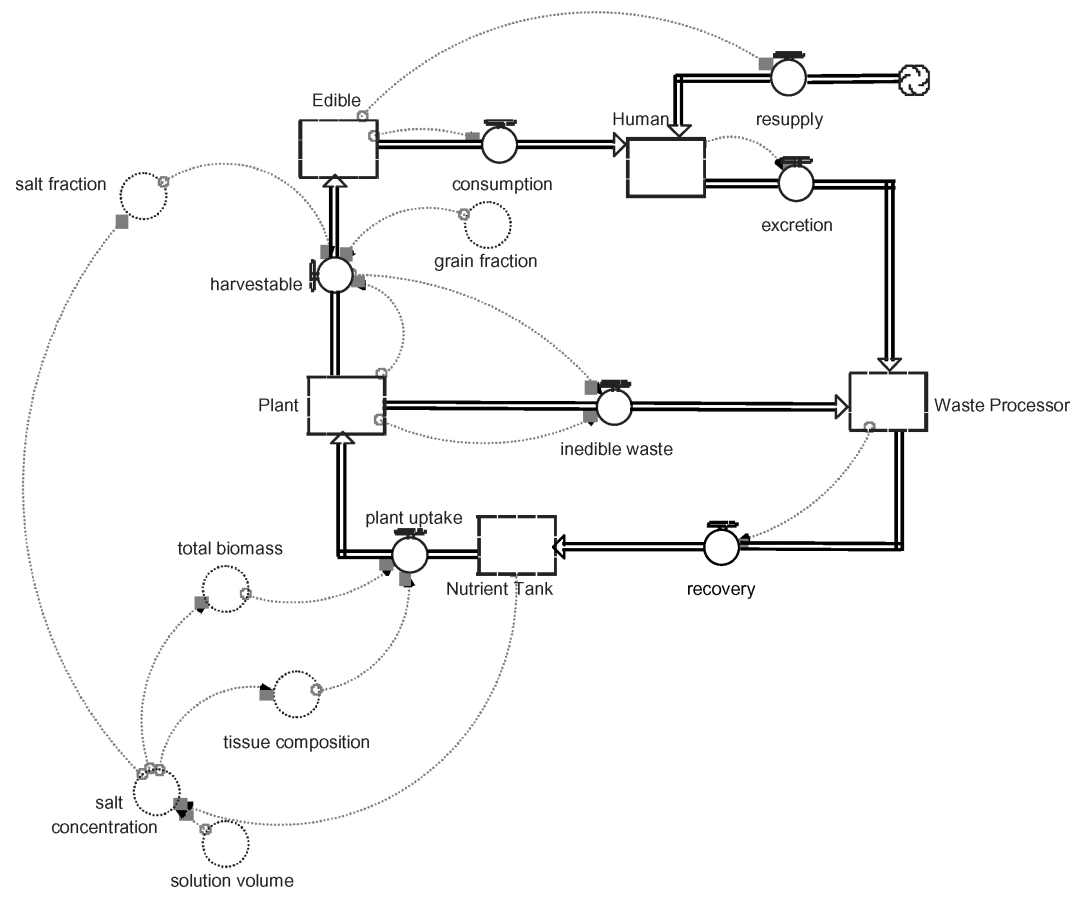

Figure 6. A schematic representation of element cycling in a biological life support system. Some adjustments in the given model were added (not shown) to test further resupply/contamination scenarios (i.e., for $\mathrm{Na}^{+}$and $\mathrm{I}^{-}$) or $\mathrm{F}$ loss by $\mathrm{CaF}_{2}$ solid phase formation.

\section{Simulation Models}

With the aforementioned data, simulation models were created to characterize these elements and their mass transfers in a BLSS. The basic simulation scenario is given (Figure 6). The model has three main components, stocks ( $\square$ ), flows (valves), and converters (O). The stocks are reservoirs that accumulate the target element, thus they can act as both, sources and sinks. The flows represent pipes that deliver materials to and from stocks. The converters contain equations or coefficients used to help define and regulate the flows. The dashed lines with arrows (connectors) represent dependencies (relationships) between components. For example, excretion (a flow) is dependent on the Human stock; resupply (a flow) is dependent on how much target element exists in the Edible stock; plant uptake (a flow) is dependent on total biomass (a converter) + tissue composition (a converter) equations (Figure 6). The resupply flow represents importation of the target element from outside the system into the human diet. This would occur if sub-adequate amounts were being provided to the Human 
stock via the Edible stock. The grain fraction converter (Figure 6) is the proportion of food supplied by grain crops. Based on data from our hydroponic studies, we assumed that grains would not accumulate Na, F, or I. Therefore, if grain fraction $=1$, then no elements will enter the Human stock from plants (100\% resupply required). Based on this simple design, several scenarios were simulated for each element.

\section{Sodium}

The model daily human requirement was 130.4 mmoles ( $3 \mathrm{~g}$ ) Na per person per day. If no $\mathrm{Na}$ came from crops (grain fraction $=1$ ) and all $\mathrm{Na}$ was from resupply, then plant productivity (total biomass) declined $10 \%$ within 230 days (7.5 months) and the corresponding nutrient solution $\mathrm{Na}$ concentration reached $50 \mathrm{mM}$. If we included non-grain crop plants to supply some of the human $\mathrm{Na}$ requirement then the system eventually reached equilibrium. For example, $20 \%$ non-grain crops resulted in an end of resupply by 1.7 years, at an equilibrium concentration of $12.4 \mathrm{mM} \mathrm{Na}$ in the nutrient solution. If the nongrain component increased to $40 \%$ (typical of a BLSS diet), the resupply ended in 11 months, with a similar Na nutrient solution concentration $(12.4 \mathrm{mM} \mathrm{Na})$. However, if we assumed that the crew would continue to use $\mathrm{Na}$ to flavor meals, such as $10 \%$ of their daily requirement (13 mmoles daily resupply) and we had $40 \%$ non-grain crops, then the input to the human stock became rather large. Sodium consumption passed the recommended 130.4 mmoles daily intake by 83 days and would increase another $50 \%$ by 616 days (1.7 years). In this scenario, plant productivity would remain within $90 \%$ of set point for well over 6 years. It is interesting to note that non $\mathrm{Na}$ accumulating crops (Chenopods) could supply the total human daily Na requirement (based on $50 \mathrm{~m}^{2}$ per person growing area). Including additional $\mathrm{Na}$ to the system via condiments and flavor enhancements would likely affect the crew's intake level sooner than it would affect plant productivity.

\section{Fluoride}

Since $\mathrm{F}$ will exist primarily as $\mathrm{F}^{-}$in the BLSS, the models simulated only $\mathrm{F}^{-}$effects. In a worst case scenario, [i.e., no $\mathrm{F}$ precipitate formation, no $\mathrm{F}$ from crops (grain fraction $=1$ )], and a human intake of $211 \mu$ moles per day), total plant biomass dropped $10 \%$ within 1.6 years, at a corresponding nutrient solution concentration of $0.24 \mathrm{mM} \mathrm{F}^{-}$. With $20 \%$ non-grain crops, total biomass dropped approximately $9 \%$ by the eighth year and resupply was no longer required. With $40 \%$ non-grain crops, resupply ended in 6.8 years. However, $\mathrm{CaF}_{2}$ precipitates form when solution $\mathrm{F}^{-}$values approach $0.3 \mathrm{mM}$. Even with no crop recycling (100\% resupply), nearly all the human excreted 
F would likely become bound in a solid phase with nutrient solution Ca. The model results suggest a nutrient solution equilibrium $\mathrm{F}$ concentration of approximately $1 \mu \mathrm{M}$, which has little if any effect on plant productivity. Based on these simulations, it appears that F may not be a concern in a BLSS as long as the solid phases do not dissolve (i.e., alkaline solutions).

\section{Iodine}

The prominent I species in the human diet is as $\mathrm{I}^{-}(118 \mu$ moles or $15 \mathrm{mg})$. In addition, the organic I species in human metabolic waste is transformed to $\mathrm{I}^{-}$by the time it leaves the body via urine (Michalke and Schramel, 1999). If no crops provided I (grain fraction $=1$ ), then plant productivity would drop $10 \%$ within seven years at a corresponding nutrient solution concentration of $3.4 \mu \mathrm{M} \mathrm{I}^{-}$. If $20 \%$ of the crop mix were non-grain crops, then plants could fulfill the entire human requirement by 294 days (9.5 months) or 162 days (5 months) with $40 \%$ of the food provided as non-grain crops.

A potential problem exists if water iodination is used as a bactericidal treatment. Research by Wiederhoeft et al. (1999) reported that they could reduce residual $\mathrm{I}^{-}$in potable water from approximately 2 to $0.28 \mathrm{ppm}(2.2 \mu \mathrm{M})$. With a daily water allotment of approximately $25 \mathrm{~L}$ per person (Parker et al., 1999), the plant system would receive an additional $55 \mu$ moles of $\mathrm{I}^{-}$each day. Based on the simulation ( $40 \%$ non-grain crops), human I ingestion would double within 5 days and total plant biomass would drop 10\% within 61 days ( 2 months). Based on the simulation results, the acceptable limits for residual I should be lowered. If residual $\mathrm{I}^{-}$was decreased $90 \%$ then the system could run for 663 days (1.8 years) before reaching a 10\% decline in plant biomass (nutrient solution $\mathrm{I}=3.6 \mu \mathrm{M}$ ) at a mere $3 \%$ increase in daily human I intake.

\section{CONCLUSIONS}

The process of characterizing element cycling through a BLSS requires inputs at several levels. Based on reasonable inputs, simulations can be constructed to help guide future systems studies and the eventual development of a BLSS or other closed life support systems. This work used plant and geochemical data for constructing simple simulations of human essential element cycling in a BLSS.

The daily addition of $\mathrm{F}$ to a BLSS might not result in any net nutrient solution $\mathrm{F}$ accumulation because of the formation of $\mathrm{CaF}_{2}$ solids at $\mathrm{Ca}$ concentrations adequate for plant growth. Iodine cycling reached an acceptable steady state in the simulation model, unless residual I was also added to the system via bactericidal water treatment. Low residual I levels that have been used by NASA in the past may result in excessive I problems in both plant 
and human systems within months of operation. A mixed cropping scenario would supply the daily human Na requirements. The addition of even $10 \%$ more $\mathrm{Na}$ to improve food palatability might result in excessive $\mathrm{Na}$ uptake by the crew prior to any deleterious effect is seen in crops. In fact, $\mathrm{Na}$ may be the biggest challenge in element cycling in a BLSS. Sodium is heavily relied upon as a flavor enhancer and it is not easily separated from other elements in the nutrient-rich waste stream which feeds the cropping system.

\section{ACKNOWLEDGMENTS}

We thank Lisa Ruffe for her lab assistance with the Na studies at the Kennedy Space Center (KSC), Justin and Melissa Crane for their lab assistance with the F and I studies, and the analytic chemistry staff at KSC and Utah State University. Financial support was provided by a NASA/GSRP fellowship.

\section{REFERENCES}

Bar-Yosef, B., and R. Rosenberg. 1988. Response of corn and tomato plants to fluorine concentration in solution culture. Agronomy Journal 80: 173-177.

Barta, D. J., J. M. Castillo, and R. E. Fortson. 1999. The biomass production system for the bioregenerative planetary life support systems test complex: Preliminary designs and considerations. SAE Technical Paper 1999-012188. 25th International Conference on Environmental Systems, Denver, Colorado. Warrendale, PA: SAE.

Böszörményi, Z., and E. Cseh. 1960. The uptake and reduction of iodate by wheat-roots. Current Science 29: 340-341.

Brownwell, P. F. 1979. Sodium as an essential micronutrient element for plants and its possible role in metabolism. Advances in Botanical Research 7: $117-224$.

Bugbee, B. G, and F. B. Salisbury. 1988. Exploring the limits of crop productivity. I. Photosynthetic efficiency of wheat in high irradiance environments. Plant Physiology 88: 869-878.

Colombo, R., D. Putnam, and R. Sauer. 1978. Microbial check valve for Shuttle. ASME Technical Paper 78-ENAS-27. 8th Intersociety Conference on Environmental Systems, San Diego, California. Warrendale, PA: SAE.

Drysdale, A. 1995. Space habitat options and advanced life support design constraints. SAE Technical Paper 951690. 25th International Conference on Environmental Systems, San Diego, California. Warrendale, PA: SAE.

Edeen, M. A., D. J. Barta, and R. Spanarkel. 1993. Evaluation of wheat growth and chamber performance in the regenerative life support systems test bed. SAE Technical Paper 932172. 23rd International Conference on Environmental Systems, Colorado Springs, Colorado. Warrendale, PA: SAE. 
Elrashidi, M. A., and W. L. Lindsey. 1986. Chemical equilibria of fluorine in soils: A theoretical development. Soil Science 141: 274280.

Fuge, R., and C. C. Johnson. 1986. The geochemistry of iodine-a review. Environmental Geochemistry and Health 8: 31-54.

Gillman, P. L, J. E. Davis-Street, V. M. Greer, R. E. Serfass, and S. M. Smith. 2001. Iodine intake and excretion: Closed chamber studies using iodine as a bactericidal agent. Federation of American Societies for Experimental Biology Journal 15: A971.

Hara, T., Y. Sonoda, and I. Iwai. 1977. Growth response of cabbage plants to sodium halides under water culture conditions. Soil Science and Plant Nutrition 23: 77-84.

Joepke, P., M. Bahadir, J. Fleckenstein and E. Schnug. 1996. Iodine determination in plant materials. Communications in Soil Science and Plant Analysis 27: 741-751.

Lane, H. W., E. Grigorov, C. T. Bourland, A. Agureev, D. Pierson, and V. Dobrovolsky. 1996. Nutritional requirements for International Space Station missions up to 360 days. NASA-JSC Technical Memorandum 28038. Washington, DC: National Aeronautics and Space Administration.

Lindsey, W. L. 1979. Chemical Equilibria in Soils. New York: John Wiley \& Sons.

Mackowiak, C. L., and P. R. Grossl. 1999. Iodate and iodide effects on iodine uptake and partitioning in rice (Oryza sativa $\mathrm{L}$.) grown in solution culture. Plant and Soil 212: 135-143.

Mackowiak, C. L., P. R. Grossl, and B. G. Bugbee. 2003. Biogeochemistry of fluoride in a plant-solution system. Journal of Environmental Quality 32: 2230-2237.

Mackowiak, C. L., P. R. Grossl, and K. L. Cook. 2005. Iodine toxicity in a plant-solution system with and without humic acid. Plant and Soil 269: 141-150.

Mackowiak, C. L., G. W. Stutte, R. M. Wheeler, L. M. Ruffe, and N. C. Yorio. 1999. Tomato and soybean production on a shared recirculating hydroponic system. Acta Horticulturae 481: 259-266.

Michalke, B., and P. Schramel. 1999. Iodine speciation in biological samples by capillary electrophoresis-inductively coupled plasma mass spectrometry. Electrophoresis 20: 2547-2553.

McQuaker, N. R., and M. Gurney. 1977. Determination of total fluoride in soil and vegetation using an alkali fusion-selective ion electrode technique. Analytical Chemistry 49: 53-56.

National Academy of Sciences. 1989. Diet and Health: Implications for Reducing Chronic Disease Risk. Washington, DC: National Academy Press.

Neilsen, F. H. 1998. Ultratrace elements in nutrition: Current knowledge and speculation. Journal of Trace Elements in Experimental Medicine 11: 251-274. 
Neilsen, F. H. 2000. Importance of making dietary recommendations for elements designated as nutritionally beneficial, pharmacologically beneficial, or conditionally essential. Journal of Trace Elements in Experimental Medicine 13: 113-129.

Parker, D. R., W. A. Norvell, and R. L. Chaney. 1995. GEOCHEM-PC-A chemical speciation program for IBM and compatible personal computers. In: Chemical Equilibrium and Reaction Models, eds. R. H. Loeppert, A. P. Schwab, and S. Goldberg, pp. 253-269. Madison WI: ASA and SSSA.

Parker, D. S., E. W. O’Conner, and R. Bagdigian. 1999. ISS water reclamation system design. SAE Technical Paper 1999-01-1950. 29th International Conference on Environmental Systems, Denver, Colorado. Warrendale, PA: SAE.

Richards, L. A. 1954. Diagnosis and Improvement of Saline and Alkali Soils. United States Salinity Laboratory, Agriculture Handbook No. 60. Washington, D.C: U.S. Government Printing Office.

Silverstein, J., G. M. Brion, R. Barkley, A. Dunham, C. Hurst, P. Todd, and J. Schulz. 1994. Contaminant accumulation in space water recycle systems. Acta Astronautica 33: 317-338.

Spears, J. W. 1999. Reevaluation of the metabolic essentiality of the minerals: Review. Asian Australasian Journal of Animal Sciences 12: 1002-1008.

Stevens, D. P., M. J. McLaughlin, and A. M. Alston. 1997. Phytotoxicity of aluminum-fluoride complexes and their uptake from solution culture by Avena sativa and Lycopersicon esculentum. Plant and Soil 192: 81-93.

Stutte, G. W., C. L. Mackowiak, N. C. Yorio, and R. M. Wheeler. 1999. Theoretical and practical considerations of staggered crop production in a BLSS. Life Support and Biosphere Science 6: 287-291.

Subbarao, G. V., C. L. Mackowiak, and R. M. Wheeler. 1999. Recycling of $\mathrm{Na}$ in advanced life support: Strategies based on crop production systems. Life Support Biosphere Science 6: 153-160.

Ulthus, E. O., and C. D. Seaborn. 1996. Deliberations and evaluations of the approaches, endpoints and paradigms for dietary recommendations of the other trace elements. Journal of Nutrition 126(9S): 2442S-2459S.

Umaly, R. C., and L. W. Poel. 1971. Effects of iodine in various formulations on the growth of barley and pea plants in nutrient solution culture. Annals of Botany 35: 127-131.

Wheeler, R. M, and R. F. Strayer. 1997. Use of bioregenerative technologies for Advanced Life Support: Some considerations for BIO-Plex and related testbeds. NASA Technical Memorandum 113229, Washington, DC: National Aeronautics and Space Administration.

Wheeler, R. M., G. W. Stutte, G. V. Subbarao, and N.C. Yorio. 2001. Plant growth and human life support for space travel. In Handbook of Plant 
and Crop Physiology, ed. M. Pessarakli, pp. 925-941. New York: Marcell Dekker, Inc.

Wheeler, R. M., C. L. Mackowiak, G. W. Stutte, J. C. Sager, N. C. Yorio, L. M. Ruffe, R. E. Fortson, T. W. Dreschel, W. M. Knott, and K. Corey. 1996. NASA's biomass production chamber: a testbed for bioregenerative life support studies. Advances in Space Research 18: 215-224.

Wiederhoeft, C. J., J. R. Schultz, W. F. Michalek, and R. L. Sauer. 1999. Reduction in the iodine content of shuttle drinking water: lessons learned. SAE Technical Paper 1999-01-2117. 29th International Conference on Environmental Systems, Denver, Colorado. Warrendale, PA: SAE. 